Dutch Government and Politics 


\section{Dutch Government and Politics}

Rudy B. Andeweg

and

Galen A. Irwin

Macmillan Education 
ISBN 978-0-333-47474-7 ISBN 978-1-349-22931-4 (eBook)

DOI 10.1007/978-1-349-22931-4

(c) Rudy B. Andeweg and Galen A. Irwin 1993

Softcover reprint of the hardcover 1st edition 1993

All rights reserved. For information, write:

Scholarly and Reference Division,

St. Martin's Press, Inc., 175 Fifth Avenue,

New York, N.Y. 10010

First published in the United States of America in 1993

ISBN 978-0-312-09672-4

Library of Congress Cataloging-in-Publication Data

Andeweg, R. B.

Dutch politics and government / Rudy B. Andeweg and Galen A. Irwin.

p. $\mathrm{cm}$.

Includes bibliographical references (p. ) and index.

ISBN 978-0-312-09672-4

1. Netherlands-Politics and government-1945- I. Irwin, Galen

A. II. Title.

JN5803.A53 1993

$320.9492-\mathrm{dc} 20$

93-6702

CIP 
To Jan Andeweg and Arnold Irwin who inspired our interest in politics

and for Esther, David, Monica, and Mark whom we in turn perhaps may inspire 


\section{Contents}

List of Tables, Figures, Exhibits and Maps xi

Preface

xiv

Acknowledgements

xviii

1 The Country and the People

A small country

The struggle against the water

Boundaries i V

Historical boundaries $\quad 6$

The language boundary $\quad 6$

$\begin{array}{ll}\text { Political and religious boundaries } & 7\end{array}$

Recent history 11

The people $\quad 13$

Religious groups 13

$\begin{array}{ll}\text { Social class } & 15\end{array}$

The structure of the Dutch economy 16

$\begin{array}{ll}\text { Trade relations } & 19\end{array}$

$\begin{array}{ll}\text { Conclusion } & 21\end{array}$

2 A Country of Minorities 23

Three threats to stable government 23

Minorities $\quad 23$

Two cleavages $\quad 25$

Pillarisation $\quad 27$

Consociational democracy $\quad 33$

Alternative interpretations $\quad 40$

Depillarisation and its consequences $\quad 44$

3 Political Parties and the Party System 50

Historical development of the parties $\quad 50$

Christian Democrats $\quad 50$ 
Socialists $\quad 53$

Liberals $\quad 55$

Other parties $\quad 56$

Party organisation $\quad 58$

Party structure $\quad 58$

Party membership $\quad 63$

Party finances $\quad 65$

A decline of parties? $\quad 68$

$\begin{array}{ll}\text { Political party system } & 70\end{array}$

The numerical criterion $\quad 70$

Dimensionality $\quad 74$

4 Elections $\quad 79$

Characteristics of the electoral system $\quad 80$

Few shall be chosen $\quad 80$

The simple act of voting $\quad 81$

Absence of geographical representation $\quad 84$

$\begin{array}{ll}\text { Extreme proportionality } & 87\end{array}$

$\begin{array}{ll}\text { Parties and campaigning } & 89\end{array}$

Candidate selection $\quad 89$

Campaigning $\quad 92$

Electoral behaviour $\quad 96$

From a structured to an open model 96

Party identification $\quad 100$

Ideology and issues 101

Candidates 106

$\begin{array}{ll}\text { Conclusion } & 107\end{array}$

5 The Cabinet 108

$\begin{array}{ll}\text { Building the governing coalition } & 108\end{array}$

Procedures of cabinet formation 109

Attempts at reform 114

Coalition theory and Dutch cabinets 118

Collective and collegial government 123

The position of the Prime Minister 123

The politicisation of the cabinet 128

6 Parliament 134

$\begin{array}{ll}\text { Parliamentary organisation and procedures } & 137\end{array}$

The structure of Parliament 139 
Parliamentary procedures

Executive-Legislative relations

From institution to arena

The paradox of parliamentary activism

Parliament as a marketplace

The coexistence of institution, arena, and marketplace

Parliament and the people

\section{The Policy-Making Process: Territorial}

Centralisation and Functional Decentralisation $\quad 158$

The territorial dimension

Provincial government

Municipal government

160

Functional decentralisation

The incorporation of interest groups 164

The fragmentation of the bureaucracy 176

The quest for control

8 Socio-Economic Policy

The return of the 'Dutch disease'

The size of the labour force

Rising unemployment

Combating unemployment

The size of the public sector

The growth of the welfare state 194

Reducing the public sector 199

The budget deficit 206

Natural gas and the 'Dutch disease' 207

The financing deficit reduced 209

Conclusion $\quad 210$

9 Foreign Policy 212

The constants of Dutch foreign policy 212

From staunch ally back to neutral state? 214

European integration versus Atlantic orientation? 220

Interests versus idealism? 225

Foreign policy constants reexamined 227 
x Contents

10 The Capability of a Fragmented System 229

Decision by negotiation $\quad 229$

The constraints of consensus $\quad 231$

An underlying consensus 231

The crucial role of experts 232

Accepted tie-breakers 233

The political role of the judiciary 234

'Brussels' as a scapegoat 237

Capability and legitimacy 238

Further Reading 241

Main Data Sources 245

$\begin{array}{ll}\text { Bibliography } & 246\end{array}$

$\begin{array}{ll}\text { Index } & 256\end{array}$ 


\section{List of Tables, Figures, Exhibits and Maps}

\section{Tables}

1.1 Employment in various sectors, $1950-88$

1.2 Percentage of Dutch imports and exports by country (1988)

2.1 The structure of the Dutch pillars

2.2 Priests in the Catholic Church, 1960-70 46

2.3 The changing rules of Dutch politics 48

3.1 Party membership and membership as a percentage of the party vote

3.2 Number of parties contesting the elections and number of parties achieving representation 1918-89

4.1 Distribution of the population according to the structured model of voting behaviour

4.2 Electoral choice according to the structured model of voting behaviour

4.3 Vote distribution within ideological heartlands and battlefield, 1989

5.1 Duration of Cabinet formations and Cabinets, 1945-89

5.2 Prime Ministers and composition of Cabinets

5.3 Technical expertise and political experience in ministerial (first) appointments, 1848-1986

6.1 Use made of assorted parliamentary rights, 1956-89 149

6.2 MPs' opinions on executive-legislative relations (1990)

6.3 MPs' perceptions of executive-legislative relations (1990) 
7.1 Personnel and budgets of government departments, 1992

8.1 Percentage of the population aged 15-64 holding employment (1987)

8.2 Participation of potential labour force by age and sex in the Netherlands, the USA, and Sweden (1980 and 1987)

8.3 Premiums for social insurance programmes

8.4 Expenditures for disability, early retirement, welfare, and unemployment $1980-8$

10.1 Trust in Dutch politics 1971-89

\section{Figures}

2.1 Divisions within Dutch society

2.2 Lijphart's typology of democracies

3.1 Average positions of party candidates on a Left-Right scale

3.2 Average positions of party candidates with regard to income differences and euthanasia

4.1 Voter turnout 1966-91

4.2 Distribution of the electorate over the parties' ideological heartlands and battlefield, 1989

6.1 Seating arrangements in the Second Chamber of Parliament

8.1 Growth of the public sector, tax burden, and premiums 1970-92

\section{Exhibits}

1.1 Important dates in Dutch history 11

3.1 Dutch political parties at a glance 60

4.1 What a Dutch ballot-paper looks like $\quad 82$

4.2 Distributing parliamentary seats, $1989 \quad 88$

4.3 Election results since $1945 \quad 105$

6.1 The interior design of the Second Chamber of Parliament

7.1 Coordinating Dutch EC policies 183

8.1 The RSV story 203

8.2 The disability problem 204 
List of Tables, Figures, Exhibits and Maps xiii

\section{Maps}

1.1 The Netherlands: provinces and major cities 


\section{Preface}

The Dutch political system has long attracted the attention of political scientists outside the Netherlands, although the country ceased to be one of the world's great powers some centuries ago. It was put on the map of comparative politics largely through the writings of scholars such as Hans Daalder and Arend Lijphart, who used it as a theory-driven case-study to explain how deep social divisions need not preclude political stability. It has been not only as a consociational democracy that theoretical concerns prompted study of the Dutch polity: students of electoral systems were drawn by its extreme form of proportional representation; coalition theorists were puzzled by its stubborn deviation from the rule that governing combinations have to be minimal-winning; for those interested in the role of pressure groups, it was a showcase of neo-corporatist arrangements. Because so many aspects of Dutch politics featured in some debate in comparative politics, many papers, articles, and books were written for an audience wider than the relatively small but active band of Dutch political scientists. As a result, there is now a sizeable body of English-language literature on Dutch politics, but it is fragmented as each individual contribution is devoted to a single specific aspect. In English, or even in Dutch, there are few systematic treatments of the Dutch political system as a whole. This book is an attempt to redress that imbalance.

It would have been much easier, however, if we had set out to write this book some 25 years ago. Until the 1960s Dutch political culture, voting behaviour, the party system, and consociational and neo-corporatist policy-making arrangements all seemed impervious to change, as if they had reached the end-state of their respective developments. In the mid-1960s political life was full of change everywhere in Western Europe, but the changes seemed to be faster and more radical in the Netherlands. At the time of writing some features of Dutch politics, such as most of the institutional frame- 
work, appear to have escaped change altogether and some of the changes have subsided, (perhaps temporarily), while others are still going on. The dust has not yet settled, and maybe it never will. In our attempt to explain Dutch politics it is often not sufficient to provide a snap-shot of the present situation; we have to describe how it was before, and in what direction it has been developing.

The first two chapters provide an introduction to the country and the society that form the basis for the Dutch political system. Chapter 1 provides background information on the country, its historical development, its people, and its economy. It points to the political effects of factors such as the artificiality of the country's borders, the struggle against the water, and the openness of the economy. Chapter 2 describes the divisions in Dutch society and their political consequences. It does so by reviewing the theory of consociational democracy and the critique of that theory, to the extent that both apply to the Dutch case. It discusses the extent to which developments in society and politics have brought an end to the era of consociationalism in the Netherlands.

Chapters 3-7 examine the principal structures of the Dutch political process and the key actors therein. We begin with the input-side of the political system, and gradually work our way to the institutions that are central in the conversion of demands into policies.

Chapter 3 introduces the various Dutch political parties, their historical and ideological development, and their organisation. It continues by analysing the party system, often described as one of the most multi of multi-party systems. The Dutch electoral system has similarly been described as an extreme version of proportional representation. Chapter 4 explains the electoral system and its effects on parties and voters. It ends with an analysis of voting behaviour in the Netherlands and makes clear why elections fail to produce conclusive outcomes. The absence of an electoral or parliamentary majority in the Netherlands has led to coalition government. Chapter 5 describes how these coalitions come about and to what extent they deviate from the predictions of coalition theory. It goes on to show the impact of coalitions on decision-making in the Dutch Council of Ministers. Chapter 6 is devoted to the Parliament and to executivelegislative relations. Although a parliamentary system, Dutch constitutional documents and political culture still retain elements of a separation of powers. The chapter traces this ambivalence through 
time and discusses its consequences. Chapter 7 rounds out this part by examining decentralisation within the Dutch political system. It looks at the roles played by local government, and in particular by the Dutch bureaucracy and interest groups. Attention is given to the incorporation of interest groups into the system, as the Netherlands is often described as a classic example of neo-corporatist policy-making.

All these chapters take the impact of the important changes in Dutch society and politics since the mid-1960s explicitly into account.

Following the exploration of the policy-input and policy-conversion mechanisms in the middle section, it seems only logical to turn our attention to the policy outputs. This is easier said than done, as a comprehensive analysis of policy outcomes in all fields is well beyond our reach. We have, therefore, selected two policy fields, socioeconomic policy and foreign policy, to serve as examples. Chapter 8 discusses socio-economic policy primarily because it is an example of a policy field that is well endowed with neo-corporatist arrangements. It describes the development of the Dutch welfare state (one of the largest in the world), and the government's reactions to recent socio-economic problems related to the size of the welfare state. Chapter 9 is devoted to foreign policy, because it stands for those policy fields that are relatively devoid of neo-corporatist organisations. Whereas domestic organisations are not very active in Dutch foreign policy, the Dutch government is the second most active country in the world when it comes to membership in international organisations. Foreign policy is, therefore, discussed in relation to three of these organisations: NATO, the EG, and the UN.

In addition to the contrast in the way policies are made, these two fields have also been selected because they achieved some notoriety in the form of two so-called 'Dutch diseases'. The socio-economic Dutch disease is understood as the excessive reliance on temporary sources of income (i.e, natural gas) to pay for permanent expenditure programmes (i.e, the welfare state). In international relations 'Hollanditis' is the second Dutch disease, referring to a perceived return to neutralism in the decade before the end of the Cold War. Chapters 8 and 9 in this part examine the extent to which these two diseases have been diagnosed correctly.

Chapter 10 concludes this book by discussing the political fragmentation that has emerged as a common theme in the preceding chapters: pillarisation, the multi-party system, propor- 
tional representation (PR), coalition government, specialisation as a characteristic of elite recruitment, sectorisation and functional decentralisation. It places this fragmentation in its proper perspective by (re)introducing some of the integrating mechanisms that also exist in the form of an underlying consensus, the precedence of expert knowledge over ideological dogmas, the existence of tie-breakers such as the judiciary and scapegoats such as 'Brussels'. Chapter 10 ends by returning to a question posed at the end of Chapter 1 about the contribution of politics to the comparatively high level of life satisfaction in the Netherlands.

The aim of the book is to combine a detailed and up-to-date analysis of Dutch politics with a comparative perspective in a form accessible to both a Dutch and a non-Dutch speaking readership. Such a combination is difficult to achieve, even though it helps that one author is an American who has lived and worked in the Netherlands for 20 years, and the other is a Dutchman who studied and worked for some time in the USA and UK. We owe a great deal to the advice and assistance of others, not least to the foreign students and other visitors who led us to lecture them about Dutch politics and asked so many pertinent questions. We would like especially to express our gratitude to the Leyden colleagues who kindly read first drafts, pointed out mistakes and offered suggestions for improvements: Hans Daalder, Ron Hillebrand, Joop Van Holsteyn, Ruud Koole, Peter Mair, Hans Oversloot, Alfred Van Staden, Theo Toonen, and Jouke de Vries. We owe a special debt to Vincent Wright, who provided countless penetrating questions and critical comments, and to our publisher, Steven Kennedy, who cajoled us into finishing the book through many stern letters and faxes. In view of all this assistance and advice from others, it is merely out of respect for the time-honoured ritual that we acknowledge ourselves to be responsible for the remaining errors.

Leyden

January 1993
Rudy B. ANDEWEg

Galen A. Irwin 


\section{Acknowledgements}

The authors and publishers wish to thank the following for permission to reproduce copyright material:

Bohn, Stafleu, Van Loghum, for Table 2.2.

Kluwer (European Fournal for Political Research), for Table 5.3.

University of California Press, for Figure 2.2.

Every effort has been made to contact all the copyright-holders, but if any have been inadvertently overlooked the publishers will be pleased to make the necessary arrangement at the earliest opportunity. 